\title{
Moderating Effect of Impression Management On the Relationship of Emotional Intelligence and Organizational Citizenship Behavior
}

\author{
Ajay K. Jain \\ Management Development Institute, Gurgaon (India)
}

Author note

Contact: akjain@mdi.ac.in (email)

\begin{abstract}
This study has examined the moderating impact of impression management motive on the relationship of emotional intelligence (EI) and Organizational Citizenship Behaviors (OCBs). Data were collected by administering self rated questionnaires to male middle level executives $(N=250)$ based in motor cycle manufacturing organizations based in northern India. Results as analyzed through moderated regression analysis demonstrated the significant negative impact of impression management motive on the relationship of El and OCBs. However, El and impression management had predicted OCBs positively. These findings advance the research on the concepts of El, impression management and OCBs in the area of organizational psychology.
\end{abstract}

Introduction

This paper draws on writings of psychology, social psychology and sociology to develop a conceptual framework that specifies how emotionally intelligent behavior helps employees in performing organizational citizenship behaviors (OCBs) in presence of impression management motive.

\section{Organizational citizenship behavior}

The concept of OCB was first introduced by Dennis Organ $(1983,1990)$ as a "good soldier syndrome", which is necessary for the prosperity and good functioning of every organization. Organ $(1988,1990)$ defined the concept of OCB as individual behavior that is discretionary, not directly or explicitly recognized by the formal reward system, and that in the aggregate promote the effective functioning of the organization. By discretionary, we mean that behavior is not an enforceable requirement of the role or the job description that is the clearly specifiable terms of the person's employment contract with the organization, the behavior is rather a matter of personal choice, such that its omission is not gradually understood as punishable. Organ (1988) further added that our definition of OCB requires that is not directly or formally recompensed by the organization's reward system. However, Organ (1988) argued that a steady stream of 
OCBs could well determine the impression that an individual makes on a supervisor or on coworkers over a period of time. That impression, in turn, could influence the recommendation by the boss for a salary increase or promotion. The important issue here is that such returns are not to be contractually guaranteed (Organ, 1988). Furthermore, researches have shown that OCB activities are considered positively in performance appraisal of employees and interview situation (Allen \& Rush, 1998; Park \& Sims, 1989; Podsakoff, Whiting, Podsakoff, \& Mishra, 2011). But these studies did not specify the weightage given to OCB activities and what happens to employees if they do not perform OCBs.

Literature shows that OCB is largely influenced by individual attitudinal and dispositional variables rather than directly by an employee's knowledge, skills and abilities (Konovsky \& Organ, 1996; Organ \& Ryan, 1995), it is increasingly seen as an organizational asset and is thus conceptualised as a core element of employee performance (Rotundo \& Sackett, 2002). This research focuses on the role of El and impression management in performing OCB activities. A meta-analytic review done by Hoffman, Blair, Meriac, and Woehr (2007) show the importance of single factor model of OCB. In addition, results show that OCB consistently relates more strongly to attitudes than does task performance and shares a modest amount of variance with attitudinal correlates beyond task performance.

Evidence suggests that employees who are characterized as conscientious (Konovsky \& Organ, 1996) and with positive affect (George, 1991) engage in more OCBs. Research evidence also shows that social network ties (strength of friendship) are related to the performance and receipt of interpersonal citizenship behavior (Bowler \& Brass, 2006). It has also been acknowledged that individuals may engage in OCBs to enhance their image in the organization (Bolino, 1999). According to Bolino (1999) OCBs can be impression enhancing and self serving. Rioux and Penner (2001) have found three motives namely, prosocial values, organizational concerns, and impression management for OCBs. Furthermore, they found that prosocial motives were most strongly associated with OCB directed at individuals and organizational concern motives were most strongly associated with OCB directed toward at the organization. Li, Liang, and Crant (2010) have highlighted the relationship between a proactive personality and OCB through the establishment of a high-quality exchange relationship with their supervisors. Similarly, Avey, Luthans, and Youssef (2010) have found that psychological capital is positively related to extra-role citizenship behavior. Therefore, the present study is primarily concerned with understanding the role of emotional intelligence as an antecedent variable and impression management as a moderator variable and the construct of OCB as dependent variable within the dynamics of organizational behavior. Literature shows that employees have various motives for engaging in OCB.

\section{$\underline{\text { Independent Variable: Emotional Intelligence }}$}

In addition to the knowledge, skill and abilities which are traditionally associated with task performance (Organ \& Ryan 1995; McClelland, 1973), success in today's work 
organizations may require a more personal configuration of competencies, such as selfmanagement, self-presentation, empathy and interpersonal sensitivity. This set of emotional and social competencies is termed as "emotional intelligence" (e.g. Goleman, 1995; Bar-On, 1997; Mayer \& Salovey, 1997). According to Bar-On (1997), broadly speaking, emotional intelligence addresses the emotional, personal, social, and survival dimensions of intelligence, which are often more important for daily functioning than the more cognitive aspects of intelligence. Emotional Intelligence is concerned with understanding oneself and others, relating to people, and adapting to and coping with the immediate surroundings, which increases one's ability to be more successful in dealing with one's environmental demands. Bar-On (1997) has developed the Bar-On Emotional Quotient Inventory (Bar-On EQ-i). The Bar-On EQ-i is a self-report measure of non-cognitive (emotional, social and personal) intelligence, composed of 133 brief items. Bar-On has coined the term "Emotional Quotient". Bar-On (1997) has defined the concept of El as an array of personal, emotional, and social competencies and skills that influence one's ability to succeed in coping with environmental demands and pressures. According to Jain and Sinha (2005) El provides the ability to deal with stressful environments through cognitively controlled affective processes. As such one $\mathrm{El}$ is an important factor in determining one's ability to succeed in life and directly and influences one's general psychological well being (one's present mental condition or overall degree of emotional health). El is a recognized asset to the organization and is currently being integrated into the workplace. It is believed to help the management to do the job better, and help to improve their service. The development of El should be a priority in organizations because understanding of employees would help to foster a cohesive and pleasant work environment rather than having the abusive environment that currently exists (Dulewicz, Higgs, \& Slaski, 2003). McEnrue, Groves, and Chen (2009) have reviewed the studies related to the development of El among managers. These studies did not provide strong evidence of emotional intelligence because several limitations of applying El models to real life situations.

\section{Emotional intelligence and OCBs:}

El has recently received more attention through claims of its ability to predict successful individuals (Cote \& Miners, 2006). Research evidence demonstrates a significant relationship between emotional intelligence (EI) and OCBs (e.g., Cote \& Miners 2006; Jain, 2003; Singh, 2006; Sitter, 2004; Solan, 2008; Yaghoubi, Mashinchi, \& Hadi, 2011). El and OCBs have been identified as significant predictors of well-functioning individuals and organizations (Jain, 2009). Emotional intelligence had positive influence on OCB directed at the organization, but not for the OCB directed at individuals (Cote \& Miners, 2006). Solan (2008) has also found evidence of the linkages between El and OCB. Though, the relationship was not very strong. Yaghoubi, Mashinchi, and Hadi (2011) have also observed that emotional intelligence had positive impact on the OCB of followers. Similar results were also observed by Sitter (2004) who has found that leader's El had positive impact on employees' performance of citizenship behavior.

Why OCB will have positive relationship with $\mathrm{El}$. The reason may be that it enables employees to comprehend their co-workers' feelings and to respond better than 
employees with low El because of their ability to easily shift from negative to positive moods (Abraham, 1999). Staw, Sutton, \& Pelled (1994) has linked El with altruistic behavior (one form of $\mathrm{OCB}$ ) and suggested the following explanation. First, being in a good mood is reinforcing, and displaying altruism is rewarding in the sense that it enables employees to also maintain this state of mind. Second, people in good moods may be more socially interactive. Third, when employees are more satisfied (having positive emotional reactions to the job) they are more likely to be engaged in helpful behavior. Similarly, El would help in keeping the positive attitude towards the organization and people even under adverse conditions.

Based on the above analysis, the following hypothesis was proposed:

Hypothesis 1: El will have positive impact on OCBs.

\section{Moderator Variable: Impression Management}

For a truly sincere and caring management system, it is necessary to differentiate between those who behave in a genuine way and those who only "show" a behavior that looks desirable but with a motive earned toward attainment of some other goal. Such behavior may be shown for the purpose of what has come to be known in the literature as the "Impression Management". Impression management theorists suggest that a primary human motive, both inside and outside organizations is to avoid being evaluated negatively (Rosenfeld, Giacalone, \& Riordan, 1995). Social psychologists have described impression management as any behavior by a person that has the purpose of controlling or manipulating the attributions and impressions formed of that person by others (Tedeschi \& Reiss, 1981) and as behaviors initiated by a source to establish a particular identity or 'shape others' attributions of the actors' dispositions (Jones \& Pittman, 1982). Impression management involves the process of upward influence only in which attempt is made to influence someone higher in formal hierarchy of authority in the organization (Porter, Allen, \& Angle, 1983). Bradway (2002) has found that an employee's use of upward influence tactics is related to observing employee's perception of fairness and OCBs.

Initial empirical work (e.g., Kipnis, Schmidt, \& Wilkinson, 1980) has shown that a majority of upward influence attempts are directed at immediate superiors. An examination of subordinate influence has been made in the performance evaluation process (Ferris \& Judge, 1991; Ferris \& King, 1991; Villanova \& Bernardin, 1989). When one considers the many opportunities, rewards and threats in organizational settings and specifically through performance evaluation process, it seems quite reasonable to expect that people will find it advantageous to manage the impressions that others form of them, especially superiors who holds power at higher level. It has been shown that person who demonstrates ingratiating types of behaviors tend to receive favorable evaluations (e.g., Jones, 1964). An impression management perspective has been applied to number of research areas within organizational behavior and human resource management (Giacalone \& Rosenfeld, 1989). Although many individuals' associate negative connotations with impression management, however recent writings have also 
recognized the value and positive outcomes related to these behaviors (Liden \& Mitchell, 1998). As Leary and Kowalski (1990) emphasize that impression management theory does not imply that the impression management created by individuals is necessarily false. In other words, individual who seek to be viewed as dedicated to their companies may, indeed, truly be committed to their organization. In this regard, impression management perspective has evolved to describe the performance of OCB (Bolino, 1999). As indicated above, engaging in citizenship behavior in organizational settings is a viable means of achieving favorable attributions. Bolino (1999) studied the relevance of various acts of impression management in relation to citizenship behavior. Many measures of impression management include specific behaviors that OCB researchers labels as citizenship behaviors.

From impression management perspective, employees engage in citizenship behavior in a strategic manner to enhance their reputations as helpful, capable contributors (Deutsch \& Deutsch, 2006). Indeed, Flynn (2003) found that employees who engage in more frequent citizenship behaviors earn higher levels of social status from their peers. Several other studies have demonstrated that some forms of citizenship behavior are predicted by impression management motives, such as image enhancement (Finkelstein, 2006; Yun, Takeuchi, \& Liu, 2007) and ingratiation and status enhancement (Bowler \& Brass, 2006; Eastman, 1994; Snell \& Wong, 2007). Wayne and Green (1993) studied the effect of leader-member exchange on impression management and OCB. They found that one form of citizenship behavior, altruism and one form of impression management; other focused were significantly related to leadermember exchange.

Thus impression management motives facilitate in creating a desired image in the minds of all important stakeholders to gain intended results for self promotion. OCB being an extra role behavior provide a likely avenue to get indulge into such behavior for the impression management reasons. Based on above analysis the following hypothesis was derived:

\section{Hypothesis 2: Impression management will have positive impact on OCBs.}

Furthermore, researchers in the area of impression management have been interested in identifying the conditions under which, employees will behave opportunistically. Studies show that employees are positive towards the use of OCB measures during performance evaluations (Johnson, Holladay, \& Quinones, 2009). Bolino, Varela, Belen, \& Turnley (2006) suggest a positive relationship between supervisor-focused tactics of impression management and OCB ratings, while job-focused tactics are negatively related to such evaluations. Additionally, citizenship behaviors are related to positive supervisor perceptions subordinates and overall ratings of job performance. The evidence suggests therefore that OCB ratings mediate the relationship between supervisor-focused tactics of impression management and supervisor evaluations of employee likeability, and that there is a significant relationship between social influence processes (power, impression management, ingratiation etc), OCB and performance. Jain, Giga, and Cooper (2011) found the evidence which supports the impact of social 
power on Organizational Citizenship Behavior (OCB) and the role OCB may play as a mediator in the relationship between social power and personal and organizational effectiveness.

Some more recent studies show the evidence of impression management motives in OCB research. A study done by Moideenkutty (2009) demonstrated that supervisors will be more likely to provide social exchange outcomes to individuals who engage in OCBs when they do not perceive the employee's behavior as impression management. Farrell and Finkelstein (2011) explained that motive attribution and job-relatedness of the specific OCB are important factors when managers are considering providing rewards for citizenship behaviors.

Wayne and Ferris (1990) studied 24 impression management behaviors; on that basis he found three types of tactics: Job Focused, Self-Focused and Supervisory- Focused impression management behavior. They found that supervisory focused tactics affected supervisors' liking for subordinates, which in turn influenced exchange quality. In this research, impression management is measured by using Wayne and Ferris's (1990) impression management questionnaire of 24 items.

\section{Moderating Impact of Impression Management}

The study conceptualizes impression management motives as a moderator of the effects of emotional intelligence on citizenship behaviors, rather than as an independent predictor of these behaviors. El has emerged a strong positive predictor of citizenship behaviors because of personal and social competencies to work within the dynamics of social realities of the organization. It can be argued that El helps in the coexistence of self-serving and other-serving motives to benefit self and others. Impression management enhances one's involvement in citizenship behavior to get rewards and other benefits. However, the moderating impact of impression management with El makes this relationship more complex. So far no study is being conducted to see the moderating impact of impression management on relationship of El and citizenship behaviors.

Grant and Mayer (2009) have found the evidence of interactions between prosocial and impression management motives as predictors of affiliative citizenship behaviors directed toward other people and the organization. They further suggest that employees who are good soldiers and good actors are most likely to emerge as good citizens. Yun, Takeuchi, and Liu (2007) have found the moderating impact of role ambiguity on the relationship of self enhancement motive and job performance behaviors. These evidences suggest the complexity of impression management motive in influencing the OCBs.

Impression management theory and research suggests that when employees have strong impression management motives, they are careful to avoid creating a negative image in the eyes of others (Jones \& Pittman, 1982; Leary \& Kowalski, 1990). As such, we expect that employees with strong El competencies and impression management 
motives will not engage in citizenship behaviors being an extra role behavior which may jeopardize their in-role behavior and positive performance evaluation thereby. So impression management motives may reduce the positive impact of El on citizenship behavior. Employees with strong impression management motives are likely to focus on actions that are beneficial themselves rather than for others and organization. Impression management is a subset of organizational politics, and engaging in citizenship behaviors can be fruitless being time and effort consuming. Since it does not directly result into positive rewards. So employees with strong impression motives will get engage in those behavior which are directly rewarding and beneficial to them. Thus impression management motives will reduce the positive impact of El on citizenship behaviors. Past researches are inconclusive regarding the moderating impact of impression management on OCBs. Only few researchers have examined the impact of the employee's motive of impression management on job performance behaviors (cf. Grandey, Fisk, Mattila, Jansen, \& Sideman, 2005). That is why this study conceptualizes impression management as a moderator of the relationship between EI and OCBs. Based on above analysis, the following hypothesis was framed.

Hypothesis 3: Impression management will have negative moderating impact on the relationship between $\mathrm{EI}$ and OCBs.

\section{Conceptual framework for the present study}

This study has adopted the moderation model to see the relationship among these variables (Baron \& Kenny, 1986). I found the moderation model to be more suitable for our study because of the focus on studying the relationship between El and OCBs in the presence of impression management motives, rather than the relationship of $\mathrm{El}$ with impression management directly. The conceptual scheme for this study is presented in Figure 1, suggesting the direct effect of El and Impression management on OCBs and the moderating effect of impression management on the relationship between $\mathrm{El}$ and OCBs. The conceptual scheme of the present study is depicted in Figure 1.

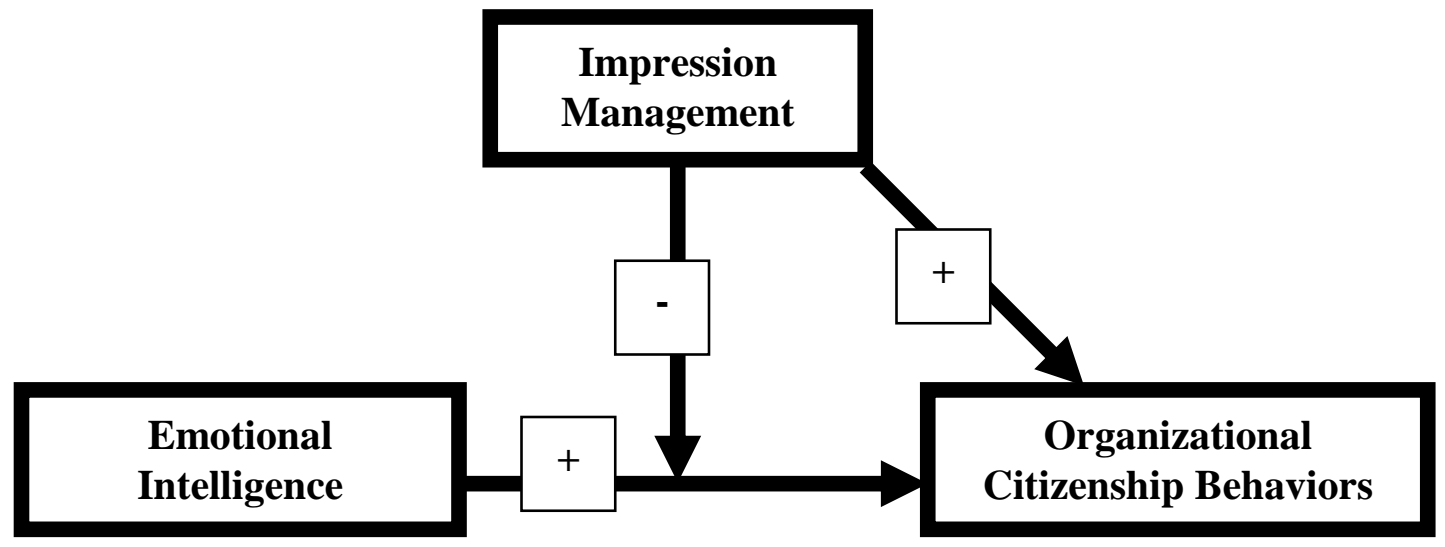

Figure 1: The Conceptual Scheme of the study

Figure 1 illustrates El as an independent variable, impression management as a moderator variable and OCBs are dependent variable. The underlying assumption is 
that impression management will have a significant moderating impact on the relationship between $\mathrm{El}$ and OCBs. The figure shows positive impact of $\mathrm{El}$ and impression management on OCBs and negative moderating impact of impression management on the relationship between $\mathrm{EI}$ and OCBs.

\section{Method}

\section{$\underline{\text { Participants \& Procedure }}$}

The sample consisted of 250 male middle level executives from four scooter manufacturing plants from the private sector based in various cities in Northern India. The organizations were chosen only from North India to control cultural variances. Participants were chosen randomly within each organization from different departments and were initially invited to meetings to discuss the process, after which they were given the choice to participate. As questionnaires were in the main administered during office hours and had the support of both HR and employee representatives, approximately $90 \%$ of those invited to meetings returned completed forms.

Although the scales from the questionnaire were selected from the wider literature and were in English, they were validated to ensure there fit within an Indian cultural context. Employees selected ranged from 25 to 45 years of age, were all male, had spent at least one year in the same organization, and the majority were married and had a graduate degree or diploma level education in engineering. The sample does not consist of female participants due to their limited representation in these organizations.

\section{Measures}

Self-report measures were used to obtain the data. El was measured by using an adapted version (Jain, 2003; Jain \& Sinha, 2005) of Bar-On (1997) EQ-i which had 21 relevant items in Indian work context. Impression Management was measured by using 24 items scale of Wayne and Ferris's (1990) which was adapted by Jain (2003). OCB was measured through the OCB questionnaire which was based on the writings of Bateman and Organ (1983), Dienesch (1994), Moorman and Blakely (1995), and Chattopadhayay (1999), Organ (1988), Smith et al. (1983), and Van Dyne, Graham, and Dienesch, R. M. (1994). The OCB questionnaire was adapted from Jain $(2003 ; 2009)$ which had 49 items. The measures used in this study were borrowed from the wider literature adapted for the Indian work setting by using exploratory factor analysis and reliability analysis. All survey items were rated on a 5-point Likert type scale ranging from 1 (true to almost no extent) to 5 (true to a very great extent).

\section{$\underline{\text { Results of Factor Analysis }}$}

Responses on the all three variables were subjected to exploratory factor analysis to confirm the validity and reliability of the questionnaires in the present Indian work context. Before administering moderating multiple regression analysis to see the impact of impression management on the relationship of El and OCBs, all questionnaires were 
subjected to exploratory factor analysis. The factor analysis results are based on principal factoring with iterations and oblique rotations using the SPSS-X. The criterion of factor loadings equal to greater than .30 with no cross-loadings on other factors and Cronbach's alpha reliability coefficient equal to or greater than .70 (Nunally, 1978) was used for the purpose of identifying valid and reliable scales.

All the measures used and adapted in this study followed the guidelines of the International Test Commission (ITC) for good test use and for best practice in assessments. The work so far carried out by the ITC to promote good practice in test adaptations (Van de Vijver \& Hambleton, 1996) is an important step towards assuring uniformity in the quality of tests adapted for use across different cultures and languages. A brief description of factors extracted by factor analysis follows.

\section{Organizational Citizenship Behavior Questionnaire}

The OCB questionnaire yielded eleven significant factors upon factor analysis. They were: Emotional Support (ES, $\alpha=.88)$, that is measured through items like, "I make myself available to my coworkers to discuss any personal or professional problems they may be facing"; Concern for Organizational Resources (COR, $\alpha=.83$ ), that is measured through items like, "I conduct personal business in company (e.g. trading, stocks, shopping etc.)"; Conservation of Time (CT, $\alpha=.70)$, that is measured through items like, "I do not spend time in extra conversation"; Organizational Pride (OP, $\alpha=.76)$, that is measured through items like, "I show pride when representing the organization in public"; Work Mindedness (WM, $\alpha=.71$ ), that is measured through items like, "I produce highest quality of work, regardless of circumstances"; Civic Virtue (CV, $\alpha=$ .71), that is measured through items like, "I utilize some creative means to complete my job effectively"; Social and Functional Participation (SFP, $\alpha=.84$ ), that is measured through items like, "I keep well informed where opinion might benefit the organization"; Altruism (ALT, $\alpha=.75)$, that is measured through items like, "I go out of my way to help co-workers with work related problems"; Sportsman Spirit (SPO, $\alpha=.70$ ), that is measured through items like, "I always find fault with what the organization is doing"; Individual Initiative (INI, $\alpha=.79$ ), that is measured through items like, "I encourage others to try new and more effective ways of doing their jobs"; and Generalized Compliance (GC, $\alpha=.70$ ), that is measured through items like, "I give advance notice if unable to come."

Although the literature highlights seven dimensions of OCB (Podsakoff et al. 2000), the reasons for achieving 11-dimensions may be related to cultural variations in the construct of OCB within the present study. However, the factor structure very much resembles the work done by Bateman \& Organ (1983), Smith et al. (1983), Organ (1988), Van Dyne et al. (1994), Moorman \& Blakely (1995) and Chattopadhayay (1999). The present study has highlighted eleven significant subscales of OCB where as other authors, for instance, Organ (1997) conceptualised only 5 dimensions of OCBs (altruism; courtesy; conscientiousness, civic virtue, and sportsmanship) and Podsakoff et al. (2000) have found seven dimensions. The overall OCB scale of 49-items was 
used for moderating regression analysis; however eleven dimensions of OCB were used as dependent variables for regression analysis.

In addition, Jain $(2003,2009)$ has developed the following items in an Indian context based on personal interviews with the executives of automobile organizations: (1) I make friendly relation to people in interest of my company; (2) I utilize some creative means to complete my job effectively; (3) I have positive attitude towards the organizational problems; (4) I try to save time and resources by completing work earlier; (5) I do my work at personal level; (6) I share my power and authority to enhance subordinates skill and confidence. These items form part of the "Civic Virtue" dimensions of OCB.

\section{El Inventory}

Using Bar-On's (1997) EQ-inventory, the present study yielded five significant factors upon factor analysis. These were named as follows: 1) Assertiveness and Positive SelfConcept (APSC, $\alpha=.74)$, 2) Impulse Control (IC, $\alpha=.72)$, 3) Positive Attitude about Life (PAL, $\alpha=.77$ ), 4) Reality Awareness (RA, $\alpha=.71$ ), and 5) Controlled Problem Solving (CPS, $\alpha=.71$ ). Overall, the five factors have some similarity with those found by Goleman (1995), Salovey and Mayer (1990), and Bar-On (1997). The majority of the items, however, did not appear to be relevant for measuring El in our sample of Indian managers, as evident by the fact that out of 133 -items only 21 were found to be factoranalytically meaningful. In this research, the total score of $\mathrm{El}$ is used to see the moderation impact of $\mathrm{El}$ on the relationship between self management and OCBs. El is measured by using Bar-On's EQ-i which is based on personality model. Personality is an integrated concept despite different dimensions like extrovert/introvert etc. For the purpose of moderation effect, El has been used as one-dimensional scale with 21 items together.

\section{Impression Management Questionnaire}

Wayne and Ferris (1990) measured impression management on supervisors through a 24-item scale that yielded only four useable factors, called (a) Job Specific Impression Management (JSIM, $\alpha=.78$ ), (b) Job Credit Outcome Focused Impression Management (JOIM, $\alpha=.76$ ), (c) Supervisory Focused Impression Management (SUIM, $\alpha=.76$ ), and (d) Self-Focused Impression Management (SFIM, $\alpha=.78$ ). The factor structure indicates that employees manage their positive impression on their supervisors by saying good things about the task they do, about the results of the task, about their supervisors and about himself or herself. Only 16-items were retained, and rests of the items were dropped because of poor factor loading and/or reliability. These four dimensions of impression management are conceptualized into impression management motives. For the present study, the total score of impression management is calculated by combing all four dimensions.

A summary for ready reference is presented in Table 1, which shows (a) the major constructs used in the study, (b) their factor-analytically derived dimensions with (c) 
number of items constituting the factors, and (d) Cronbach's alpha coefficients indicating the internal consistency for the respective factors.

\begin{tabular}{|c|c|c|c|}
\hline \multicolumn{4}{|l|}{ Table 1} \\
\hline \multicolumn{4}{|c|}{ Summary of Factors, Abbreviations, and Reliability of Scales } \\
\hline Concepts & Factors (Constructs) & $\begin{array}{l}\text { No. of } \\
\text { Items }\end{array}$ & $\begin{array}{l}\text { Cronbach's } \\
\text { Alpha }\end{array}$ \\
\hline \multirow{5}{*}{$\begin{array}{l}\text { Emotional } \\
\text { Intelligence }\end{array}$} & Assertiveness and Positive Self Concept & 4 & .74 \\
\hline & Impulse Control & 4 & .72 \\
\hline & Positive Attitude About Life & 5 & .77 \\
\hline & Reality Awareness & 4 & .71 \\
\hline & Controlled Problem Solving & 4 & .71 \\
\hline \multirow{4}{*}{$\begin{array}{l}\text { Impression } \\
\text { Management }\end{array}$} & Job Specific Impression Management & 3 & .78 \\
\hline & $\begin{array}{l}\text { Job Outcome Credit Focused Impression } \\
\text { Management }\end{array}$ & 6 & .76 \\
\hline & $\begin{array}{l}\text { Supervisory Focused Impression } \\
\text { Management }\end{array}$ & 5 & .76 \\
\hline & Self Focused Impression Management & 2 & .78 \\
\hline \multirow{11}{*}{$\begin{array}{l}\text { Organizational } \\
\text { Citizenship } \\
\text { Behavior }\end{array}$} & Emotional Support & 4 & .88 \\
\hline & Concern for Organizational Resources & 5 & .83 \\
\hline & Conservation of Time & 2 & .70 \\
\hline & Organizational Pride & 5 & .76 \\
\hline & Work Mindedness & 3 & .71 \\
\hline & Civic Virtue & 7 & .71 \\
\hline & Social and Functional Participation & 6 & .84 \\
\hline & Altruism & 4 & .75 \\
\hline & Sportsmanship & 4 & .70 \\
\hline & Individual Initiative & 5 & .79 \\
\hline & Generalized Compliance & 4 & .70 \\
\hline
\end{tabular}

\section{Results}

The principal method for analyzing the data was moderator regression analysis (Aiken \& West, 1991; Stone \& Hollenbeck, 1984; Zedeck, 1971). In step 1, total El scores were entered, on step 2, total impression management scores were entered, and on step 3, total El scores, total impression management scores and the interaction term (product 
of $\mathrm{El}$ and impression management) was added to the regression equation. The procedure is done for all 11 -factors of OCB along with total OCB score. It means a total of 12 tables $\left(1^{*} 1^{*} 12\right)$ with interaction term were generated. However, 6 tables have shown significant moderating impact of impression management.

With regard to moderator analysis, Clegg and Wall (1980) opined that moderator regression analysis may fail to report significant interactions when these are actually present. Hence, they suggest using the significance level at 0.10 rather than at the usual 0.05 . Similarly, it has been done by Batlis (1980) as well as by Sonnetag, Brodbeck, Heinbokel, and Stolte (1994).

\section{Descriptive statistics and Moderated Regression}

The descriptive statistics and a correlation matrix are displayed in Table 2. The table of zero order correlation showed that results are consistent to our first two hypotheses. Result showed that El and impression management were found to be positively correlated with OCBs.

Overall the results are consistent with all three hypotheses. El and impression management had positive impact on OCBs where as impression management moderated the relationship between El and impression management negatively. Thus, it means that impression management motives reduced the positive impact of El on OCBs. In presence of impression management motive, El had negative impact on OCBs. Figure 2 shows that impression management had significant moderating impact on the relationship of El and OCBs. Overall it explained 23 percent of variance in OCBs.

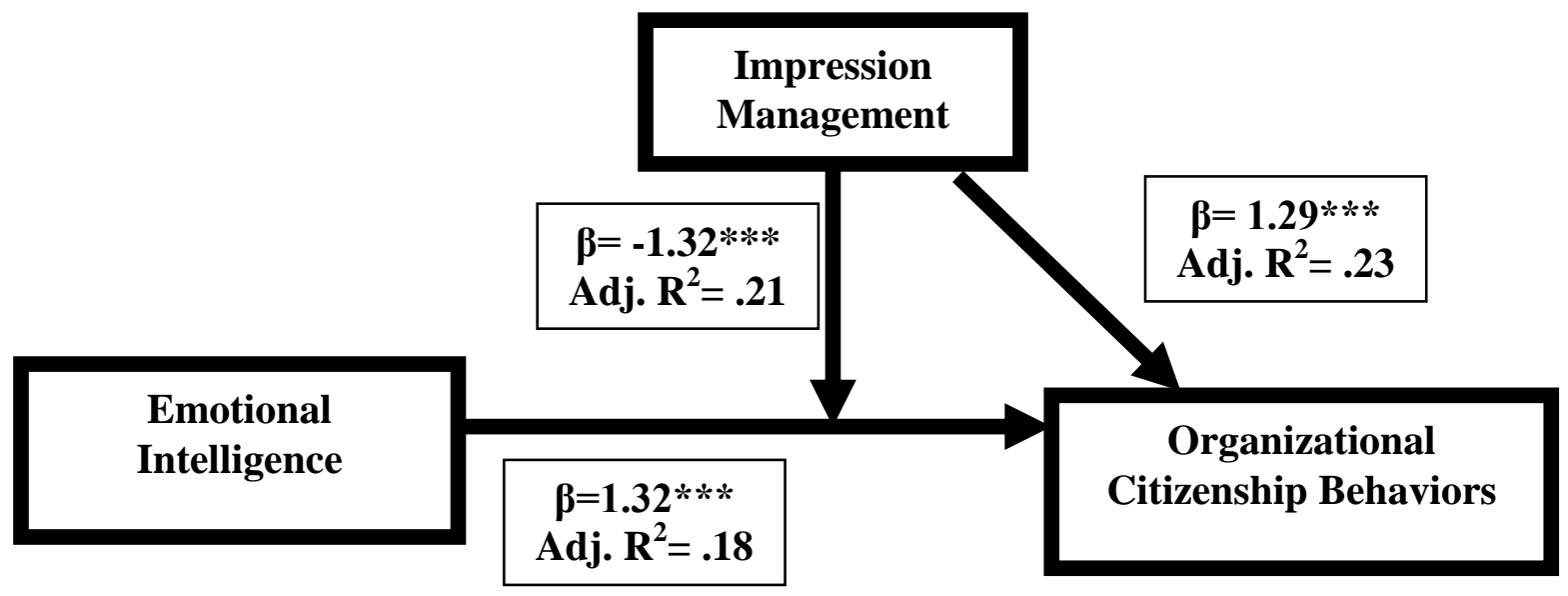

Figure 2: Results of moderated regression analysis ${ }^{* * *}$ means significance at .01 level) 
Table 2

Shows descriptive statistics and correlations across dimensions of OCB, El and Impression management

\begin{tabular}{|c|c|c|c|c|c|c|c|c|c|c|c|c|c|c|c|}
\hline Variables & Mean & SD & 1 & 2 & 3 & 4 & 5 & 6 & 7 & 8 & 9 & 10 & 11 & 12 & 13 \\
\hline 1. Emotional Intelligence & 3.871 & .502 & 1 & & & & & & & & & & & & \\
\hline 2. Impression Management & 2.982 & .496 & -.118 & 1 & & & & & & & & & & & \\
\hline 3. Emotional Support & 4.033 & .638 & .340 & .153 & 1 & & & & & & & & & & \\
\hline 4. Concern For Organizational Resources & 4.191 & .644 & .362 & -.13 & .319 & 1 & & & & & & & & & \\
\hline 5. Conservation of Time & 3.893 & .872 & .188 & .061 & .361 & .201 & 1 & & & & & & & & \\
\hline 6. Organizational Pride & 3.971 & .621 & .263 & .141 & .5 & .316 & .246 & 1 & & & & & & & \\
\hline 7. Work Mindedness & 3.952 & .638 & .173 & .307 & .412 & .252 & .214 & .416 & 1 & & & & & & \\
\hline 8. Civic Virtue & 3.883 & .555 & .259 & .168 & .597 & .294 & .297 & .559 & .412 & 1 & & & & & \\
\hline 9. Social and Functional Participation & 3.682 & .616 & .36 & .179 & .564 & .219 & .128 & .499 & .400 & .559 & 1 & & & & \\
\hline 10. Altruism & 3.721 & .614 & .114 & .103 & .382 & .016 & .196 & .367 & .219 & .375 & .427 & 1 & & & \\
\hline 11. Sportsmanship & 3.851 & .734 & .325 & -.244 & .139 & .478 & .034 & .207 & .091 & .154 & .193 & -.031 & 1 & & \\
\hline 12. Individual Initiative & 3.842 & .554 & .308 & .206 & .554 & .167 & .252 & .485 & .301 & .462 & .499 & .506 & .145 & 1 & \\
\hline 13. Generalized Compliance & 4.144 & .608 & .205 & .091 & .402 & .376 & .469 & .405 & .427 & .354 & .301 & .173 & .249 & .3 & 1 \\
\hline 14. total OCB & 3.922 & .395 & .427 & .145 & .759 & .543 & .537 & .721 & .601 & .726 & .683 & .516 & .406 & .671 & .662 \\
\hline
\end{tabular}

Note: $r=.13$ Significant at .05 level; $r=.17$ Significant at .01 level 
Results of moderating regression analysis are shown in Table 3. Results showed that EI and impression management had positive impact on OCBs. However, the impact of El was stronger compare to impression management. The beta values are significantly higher in case of El. El had no relationship with Altruism and Sportsman Spirit dimensions of OCB. Impression management had no impact on Conservation of Time, Organizational Pride, Social and Functional Participation, Altruism and Sportsman Spirit dimensions of OCB. The interaction impact of El and impression management was insignificant for Conservation of Time, Organizational Pride, Work Mindedness, Social and Functional Participation, Altruism and Sportsman Spirit dimensions of OCB.

Table 3

Results of the Moderated Multiple Regression Analysis : Predictor Variable - Emotional Intelligence, Moderator Variable - Impression Management; Criterion Variables Organizational Citizenship Behavior (OCB) with 11 dimensions

\begin{tabular}{|c|c|c|c|c|c|c|}
\hline \multirow{2}{*}{$\begin{array}{l}\text { Predictor \& Moderator } \\
\text { Criterion Variables }\end{array}$} & \multicolumn{2}{|c|}{$\begin{array}{l}\text { Main Effect of } \\
\text { Emotional } \\
\text { Intelligence (EI) }\end{array}$} & \multicolumn{2}{|c|}{$\begin{array}{l}\text { Main Effect of } \\
\text { Impression } \\
\text { Management (IM) }\end{array}$} & \multicolumn{2}{|c|}{$\begin{array}{l}\text { Interaction effect of } \\
\text { El*IM }\end{array}$} \\
\hline & $\beta$ & $\mathrm{AdjR}^{2}$ & $\beta$ & $\operatorname{Adj}^{2}$ & $\beta$ & $\operatorname{AdjR}^{2}$ \\
\hline Emotional Support & $.99^{\star *}$ & .11 & $.98^{\star \star}$ & 14 & $-.96^{\star *}$ & .15 \\
\hline $\begin{array}{l}\text { Concern for } \\
\text { Organizational Resources }\end{array}$ & $1.19^{* \star *}$ & 13 & $.97^{\star *}$ & .13 & $-1.28^{\star * *}$ & .15 \\
\hline Conservation of Time & $.72^{\star \star}$ & .03 & .74 & .04 & -.79 & .04 \\
\hline Organizational Pride & $.67^{*}$ & .07 & .66 & .09 & -.58 & .09 \\
\hline Work Mindedness & $.61^{*}$ & .03 & $.83^{\star *}$ & .12 & -.60 & .13 \\
\hline Civic Virtue & $.98^{\star \star \star}$ & .06 & $1.07^{\star \star *}$ & .10 & $-1.05^{\star \star}$ & .11 \\
\hline $\begin{array}{l}\text { Social and Functional } \\
\text { Participation }\end{array}$ & $.66^{\star \star}$ & 12 & .57 & 17 & -.42 & .17 \\
\hline Altruism & .36 & .009 & .41 & .02 & -.35 & .02 \\
\hline Sportsman Spirit & .37 & .10 & -.11 & .14 & -.11 & .14 \\
\hline Individual Initiative & $1.21^{* \star *}$ & .09 & $1.35^{\star \star \star}$ & .15 & $-1.34^{* \star *}$ & .17 \\
\hline Generalized Compliance & $1.31^{* \star *}$ & .04 & $1.48^{\star \star \star}$ & .05 & $-1.66^{\star \star *}$ & .08 \\
\hline Total OCB & $1.32^{\star \star \star}$ & 18 & $1.29^{\star \star \star}$ & .21 & $-1.32^{\star * *}$ & .23 \\
\hline
\end{tabular}

Note: ${ }^{*} p<.10,{ }^{* *} p<.05,{ }^{* * *} p<.01$

\section{Discussion}

The overall results are consistent with the hypotheses. The results from Table 2 and Table 3 showed that El had strong positive impact on different forms of citizenship behavior. These results have supported the prior research findings in this direction (e.g., Carmeli, 2003; Jain \& Sinha, 2003; Sitter, 2004; Singh, 2006). El and OCBs have been identified as significant predictors of well-functioning individuals and organizations (Jain, 2009). The claims that El has the ability to predict successful individuals are found true (Cote \& Miners, 2006). Solan (2008) has also found positive linkages between El and OCB. Though, the relationship was not very strong. Yaghoubi, Mashinchi, \& Hadi (2011) have also observed that emotional intelligence had positive impact on the OCB of 
followers. Similar results were also observed by Sitter (2004) who found that leader's El had positive impact on employees' performance of citizenship behavior.

Why El has influenced OCB positively? The reason may be that it enables employees to comprehend their co-workers' feelings and to respond better than employees with low El. High El helps them to easily shift easily from negative to positive moods (Abraham, 1999). Staw, Sutton, and Pelled (1994) have suggested that controlling mood may make employee to be more socially interactive and more satisfied with their present work and organization. Thus El helps in keeping the positive attitude towards the organization and its people even under adverse conditions.

The work of Cialdini, Kenrick, and Baumann (1982) on prosocial behavior has established the negative state relief model, and according to this model, prosocial behavior is motivated by a desire to reduce negative feelings of unhappiness or dissatisfaction. Therefore, it may be explained that El will enhances OCB by controlling the negative mood. OCB may likely to reduce the feeling of unhappiness and dissatisfaction. In contrast, Smith, Keating, and Stotland (1989) have established the idea of empathic joy as a motivator of altruistic behavior. Research indicates clearly that when an individual offers to help someone in need, his or her mood becomes more positive (Yinon \& Landau, 1987). In fact, under many conditions, even if individual is required to provide help, positive affect increases and negative affect decreases (Williamson \& Clark, 1992). Thus it means El creates a state of joy or a need for positive attitude in employees' mind which further motivates them to get engage in OCBs.

Results from table 2 and table 3 also show that impression management had positive impact on OCBs. The results confirm the presence of impression management motive in performing OCB. Originally, it was assumed that employees who engage in OCBs are good soldiers; however, Bolino (1999) proposed that such behaviors may be impression enhancing and self serving. Employees may get engage in acts of citizenship to look good or to create a positive self image in the eyes of others. The question which is not answered is about good citizens, whether they are good soldiers or good actors. Farrell and Finkelstein (2011) explained that motive attribution and job-relatedness of the specific OCB are important factors when managers are considering providing rewards for citizenship behaviors. Furthermore, Grant, and Mayer (2009) have found the evidence of interactions between prosocial and impression management motives as predictors of affiliative citizenship behaviors directed toward other people and the organization. They further suggest that employees who are good soldiers and good actors are most likely to emerge as good citizens. In a qualitative study, Snell and Wong (2007) found that OCB can be regarded as socially desirable form of organizational behavior when it was attributed to prosocial motives. Furthermore, they observed three forms of citizenship related impression management behavior, OCB attributed primarily to impression management motives; alleged pseudo-OCB concomitant with minimal compliance; and alleged pseudo-OCB concomitant with counterproductive behavior. Ingratiation, one form of impression management, was also found to be correlated with OCBs (Nguyen, Seers, \& Hartman, 2008). These results indicate that the favorable 
outcome of citizenship behavior depends on the attribution of motive by the respective supervisors whether OCB is governed by prosocial motive or impression management motive. It seems that impression management is closely linked with OCBs.

Furthermore, the main agenda of this research was to see the moderating impact of impression management motive on the relationship of El and OCBs. Results showed the negative moderating impact of impression management motive on the relationship between $\mathrm{El}$ and OCBs. Thus it means impression management reduces the positive impact of El on OCBs. Impression management motive moderate the relationship into a negative manner because of "looking good" motives play a stronger role than in being good. As explained by Farrell and Finkelstein (2011) that motive attribution and jobrelatedness of the specific OCB are important factors to explain the causes of OCBs. Results shows that Emotional support, Concern for organizational resources, Civic virtue, Individual initiative, Generalized compliance and total OCB are negatively influenced by the interaction effect of El and impression management. Leary and Kowalski (1990) noted that employee would engage in impression management behavior to facilitate the achievement of a "good organizational citizen" image. The motive of "looking good" was found to be stronger compare to El competencies in influencing the acts of OCB. In context of political environment, Ralston and Elsass (1989) noted that employees increase the use of impression management tactics. It is also possible that individuals will be more likely to engage in impression management behavior when his in-role performance is suffering. When s/he does not complete in-role assignments, $\mathrm{s} /$ he engages in impression management tactics to enhance his/her organization image of loyal and committed employee. Thus impression management motive reduces the positive impact of emotionally intelligent behavior on OCBs. Impression management may help employees in their immediate performance appraisal and advancement decisions whereas emotional intelligent behavior may have long term benefits. Impression management tactics enhance the image of being a loyal and committed employee for underlying associated benefits. It has been observed that employee demonstrate more seriousness towards their job and supervisor just before the performance appraisal period because of immediate benefits. Thus employees may prefer to use the impression management tactics to receive immediate benefits; however El may give benefits in long run.

\section{$\underline{\text { Implication, Limitations and Suggestions }}$}

This research is an empirical demonstration of impression management motive as a moderator of the relationship between El and OCBs. No research on this subject has, to date, been conducted in an Indian work context. This research advances our knowledge in the area of impression management motives in general and evidence of impression management as a moderator variable in particular. Organizational researchers and practitioners of management need to understand the dynamics of human behavior within the gamut of complex organizational dynamics. Managers and supervisors need to take a note of precaution when considering the performance review of their subordinate. They must focus on long term behavior of employees rather short term impression management motives. The literature highlights the benefits of emotional 
intelligence behavior for managers and leaders; however impression management motives may reduce the positive impact on desirable forms of organizational behavior.

El has its own contribution in improving the performance of OCB; however it becomes weaker when impression management motives are entered into the regression equation. We can conclude that any specific behavioral competency like $\mathrm{El}$ is not necessarily positive in every situation. It also depends on other individual and organizational levels variables which act as moderator or mediator for example, supervisory trust, employee commitment, perception of fairness, personal values, job satisfaction, organizational support, climate and culture of the work place can play an important role in strengthening or weakening the positive forms of organizational behavior. In future research, one may look at the impact of impression management on OCBs as moderated or mediated by one of these variables. One major limitation of this research is self reported measure of OCB which may create a common method bias. Nonetheless, these results are indicative of impression management motive in acts of citizenship is a good contribution to the literature in this area especially in Indian work context. This study is first of its kind which links El, impression management and OCBs.

\section{References}

Abraham, R. (1999). El in organizations: a conceptualization. Genetic, Social, and General Psychology Monographs, 125(2), 209-224.

Aiken, L. S., \& West, S. G. (1991). Multiple regressions: Testing and interpreting interactions. Newbury Park, CA: Sage.

Allen, T. D., \& Rush, M. C. (1998). The impact of organizational citizenship behavior on performance judgment: A field study and a laboratory experiment. Journal of Applied Psychology, 83(2), 247-260.

Avey J. B., Luthans F., \& Youssef C. M. (2010). The additive value of positive psychological capital in predicting work attitudes and behaviors, Journal of Management, 36(2), 430-438.

Bar-On, R. (1997). The Emotional quotient inventory EQ-i: Technical Manual. Toronto: Multi Health Systems.

Baron, R. M., \& Kenny, D. A. (1986). The moderator-mediator variable distinction in social psychological research: Conceptual, strategic and statistical considerations. Journal of Personality and Social Psychology, 51(6), 1173-1182.

Bateman, T. S., \& Organ, D. W. (1983). Job satisfaction and the good soldier: The relationship between affect and employee citizenship. Academy of Management Journal, 37, 299-322.

Batlis, N. C. (1980). Job involvement and locus of control as moderators of role perception: individual-outcome relationships. Psychological Reports, 13, 26-40.

Bolino, M. C. (1999). Citizenship and impression management: good soldiers or good actors? Academy of Management Review, 24(1), 82-98.

Bolino M. C, Varela, J. A, Bande, B., \& Turnley, W. H. (2006). The impact of impression management tactics on supervisor ratings of organizational citizenship behavior. Journal of Organizational Behavior, 27(3), 281-287. 
Bowler, W., \& Brass, D. J. (2006). Relational correlates of interpersonal citizenship behavior: A social network perspective. Journal of Applied Psychology, 91(1), 715.

Bradway, L. K. (2002). Effects of upward influence tactics on coworkers: An equity perspective. (Unpublished Doctoral Dissertation). University of Illinois at Chicago.

Carmeli, A. (2003). The relationship between El and work attitudes, behavior and outcomes: An examination among senior managers. Journal of Managerial Psychology, 88, 788-813.

Chattopadhyay P. (1999). Beyond direct and symmetrical effects: The influence of demographic dissimilarity on organizational citizenship behavior. Academy of Management of Journal, 42(3), 273-287.

Cialdini, R. B., Kenrick, D. T., \& Bauman, D. J. (1982). Effects of mood on pro-social behavior in children and adults. In N. Eisenberg (Ed.), Development of Pro-Social Behavior. (pp. 339-359). New York: Academic Press.

Clegg, C., \& Wall, T. (1990). The relationship between simplified jobs and mental health: A replication study. Journal of Occupational Psychology, 63(1), 289-296.

Cote, S., \& Miners, C. T. H. (2006). Emotional intelligence, cognitive intelligence, and job performance. Administrative Science Quarterly, 51(1), 1-12.

Deutsch, S. D., \& Deutsch, Y. (2006). OCB as a handicap: An evolutionary psychological perspective. Journal of Organizational Behavior, 27(2), 185-199.

Dulewicz, V., Higgs, M., \& Slaski, M. (2003). Measuring El: Content, construct and criterion-related validity. Journal of Managerial Psychology, 18(5), 405-420.

Farrell, S. K., \& Finkelstein, L. M. (2011). The Impact of motive attributions on coworker justice perceptions of rewarded organizational citizenship behavior. Journal of Business and Psychology, 26(1), 57-69.

Finkelstein, M. A. (2006). Dispositional predictors of organizational citizenship behavior: Motives, motive fulfillment, and role identity. Social Behavior and Personality, 34, 603-616.

Ferris, G. R., \& Judge, T. A. (1991). Personnel / Human resources management: A Political Influence Perspective. Journal of Management, 17, 1-42.

Ferris, G. R., \& King, T. R. (1991). Politics in human resources decisions: A walk on the dark side. Organizational Dynamics, 20, 59-71.

Flynn, F. J. (2003). How much should I give and how often? The effects of generosity and frequency of favor exchange on social status and productivity. Academy of Management Journal, 46(5), 539-553.

George, J. M. (1991). State or trait: effects of positive mood on pro-social behavior at work. Journal of Applied Psychology, 76(2), 299-307.

Giacalone, R. A., \& Rosenfeld, P. (1989). Impression management in the organization. Hillsdale, NJ: Lawrence Erlbaum Associates.

Goleman, D. (1998). Working with emotional intelligence. New York: Bantam Books.

Grandey, A. A., Fisk, G. M., Mattila, A. S., Jansen, K. J., \& Sideman, L. A. (2005). Is service with a smile" enough? Authenticity of positive displays during service encounters. Organizational Behavior and Human Decision Processes, 96(1), 3855. 
Grant, A. M., \& Mayer, D. M. (2009). Good soldiers and good actors: Prosocial and impression management motives as interactive predictors of affiliative citizenship behaviors, Journal of Business and Psychology, 24(4), 409-414.

Hoffman, B. J., Blair, C. A., Meriac, J. P., \& Woehr D. J. (2007). Expanding the criterion domain? A quantitative review of the OCB literature. Journal of Applied Psychology, 92(2), 555-566.

Jain, A. K. (2009). Exploring the relative relevance of organizational citizenship behavior and Emotional Intelligence. Journal of the Indian Academy of Applied Psychology, 35(1), 87-97.

Jain A. K. (2003). Essence and consequences of organizational citizenship behaviour: The role self management, El and impression management. (Unpublished Doctoral Dissertation). Department of Humanities and Social Sciences, Indian Institute of Technology, Kanpur, India.

Jain, A. K., \& Sinha, A. K. (2005). General health in organizations: Relative relevance of emotional intelligence, trust and organizational support. International Journal of Stress Management, 12(3), 257-273.

Jain, A. K., Giga, S. I., Cooper, C. L. (2011). Social Power as a means of increasing personal and organizational effectiveness: The mediating role of organizational citizenship behavior. Journal of Management and Organization, 17(3), 413-432.

Johnson, S. K., Holladay, C. L., \& Quinones, M. A. (2009). Organizational citizenship behavior in performance evaluations: Distributive justice or injustice? Journal of Applied Psychology, 94(4), 900-912.

Jones, E. E. (1964). Ingratiation. New York: Appleton Century Crofts.

Jones, E. E., \& Pittman, T. S. (1982). Toward a general theory of strategic selfpresentation. In J. Sulz (Ed.), Psychological perspective on the self (pp.231-253). Hillsdale, NJ: Lawrence Erlbaum Associates.

Kipnis, D., Schmidt, S., \& Wilkinson, I. (1980). Intra-organizational influence tactics: Explorations in getting one's way. Journal of Applied Psychology, 65(4), 440-452.

Konovsky, M. A., \& Organ, D. W. (1996). Dispositional and contextual determinants of organizational citizenship behavior. Journal of Organizational Behavior, 17(3), 253-266.

Leary, M. R., \& Kowlaski, R. M. (1990). Impression management: A literature review and two component model. Psychological Bulletin, 107, 34-47.

Li, N., Liang, J., \& Crant J. M. (2010). The role of proactive personality in job satisfaction and organizational citizenship behavior: A relational perspective, Journal of Applied Psychology, 95(2), 395-412.

Liden, R. C., \& Mitchell, T. R. (1988). Ingratiatory behaviors in organizational settings. Academy of Management Review, 13(4), 572-587.

Mayer, J. D., \& Salovey, P. (1997). What is emotional intelligence? In P. Salovey \& D. Sluyter (Ed.), Emotional development and emotional intelligence: Implication for educators (pp. 3-31). New York: Basic Books.

McEnrue, M. P., Groves, K., \& Shen, W. (2009). Emotional intelligence training: The role of openness to experience, self-efficacy, and receptivity to feedback in enhancing gains achieved. Journal of Management Development, 28(2), 150174. 
Moideenkutty, U. (2009). Correlates and outcomes of organizational citizenship behavior directed toward the organization, the supervisor, and co-workers: A social exchange perspective. (Unpublished Doctoral Dissertation). Temple University, Philadelphia, PA.

Moorman, R. H., \& Blakely, G. L. (1995). Individualism-Collectivism as an individual difference predictor of organizational citizenship behavior, Journal of Organizational Behavior, 16, 127-142.

Nguyen, N. T., Seers, A., \& Hartman, N. S. (2008). Putting a Good Face on Impression Management: Team Citizenship and Team Satisfaction. Journal of Behavioral and Applied Management, 9(2), 148-168.

Nunnally, J.C. (1978). Psychometric Theory. New York, McGraw Hill

Organ, D. W. \& Ryan, K. (1995). A meta-analytic review of cognitive and dispositional predictors of organizational citizenship behavior. Personnel Psychology, 48, 775802.

Organ, D. W. (1988). Organizational citizenship behavior: The good soldier syndrome. Lexington, MA: D. C. Heath.

Organ, D. W. (1997). Organizational citizenship behavior: Its construct clean up time. Human Performance, 10, 85-98.

Organ, D. W., \& Konovsky, M. (1989). Cognitive and affective determinants of organizational citizenship behavior. Journal of Applied Psychology, 74, 157-164.

Organ, D. W. (1997). Organizational citizenship behavior: Its construct clean up time. Human Performance, 10, 85-98.

Park, O. S., \& Sims, H. P., Jr. (1989). Beyond cognition in leadership: Pro-social behavior and affect in managerial judgment (working paper). Seoul National University and Pennsylvania State University.

Podsakoff, P. M., MacKenzie, S. B., Paine, J. B., \& Bachrach, D. G. (2000). Organizational citizenship behaviors: A critical review of the theoretical and empirical literature and suggestions for future research. Journal of Management, 26(3), 513-563.

Podsakoff, N. P., Whiting, S. W., Podsakoff, P. M., \& Mishra, P. (2011). Effects of organizational citizenship behaviors on selection decisions in employment interviews. Journal of Applied Psychology, 96(2), 310-326.

Porter, L. W., Allen, R. W., \& Angle, H. L. (1983). The politics of upward influence in organizations. In R. W. Allen \& L. W. Porter (Eds.), Organizational influence processes (pp. 408-422). Glenview IL: Scott, Foresman and Company.

Ralston, D. A. (1985). Employee ingratiation: The role of management. Academy of Management Review, 10(3), 477-487.

Ralston, D. A., \& Elsass, P. M. (1990). Ingratiation and impression management, In R. Giacalone \& P. Rosenfeld (Eds.), Impression management (pp. 235-249). Hillsdale, NJ: Lawrence Erlbaum Associates.

Rioux, S. M., \& Penner, L. A. (2001). The causes of organizational citizenship behavior: A motivational analysis. Journal of Applied Psychology, 86(6), 1306.

Rosenfeld, P. R., Giacalone, R. A., \& Riordan, C. A., (1995). Impression management in organizations: theory, measurement and practice. New York: Routledge. 
Rotundo, M., \& Sackett, P. R. (2002). The relative importance of task, citizenship, and counterproductive performance to global ratings of job performance: A policy capturing approach. Journal of Applied Psychology, 87(1), 66-80.

Singh, S. (2006). El among junior leaders: Relationship with organizational Citizenship. In P. Singh, J. Bhatnagar \& A. Bhandarkar's (Eds.), Future of Work: Mastering Change (pp. 253-270). National HRD Network. Excel Books. New Delhi.

Sitter, V. L. (2004). The effects of a leader's emotional intelligence on employees' trust in their leader and employee organizational citizenship behaviors. (Unpublished Doctoral Dissertation). Regent University, Virginia Beach, VA.

Smith, C. A., Organ, D. W., \& Near, J. P. (1983). Organizational citizenship behavior: Its nature and antecedents, Journal of Applied Psychology, 68, 653-663.

Smith, K. D., Keating, J. P., \& Stotland, E. (1989). Altruism reconsidered: The effect of denying feedback on a victim's status to empathetic business. Journal of Personality and Social Psychology, 57, 641-650.

Snell, R. S. \& Wong, Y. L. (2007). Differentiating good soldiers from good actors. The Journal of Management Studies, 44(6), 883-897.

Solan, A. M. (2008). The relationships between emotional intelligence, visionary leadership, and organizational citizenship behavior in continuing higher education. (Unpublished Doctoral Dissertation). Regent University, Virginia Beach, VA.

Sonnetag, S., Brodbeck, F. C., Heinbokel, T., \& Stolte, W. (1994). Stressors-burnout relationship in software development teams. Journal of Occupational and Organizational Psychology, 67(4), 327-342.

Staw, B. M., Sutton, R. I., \& Pelled, L. H. (1994). Employee positive emotion and favorable outcomes at the workplace, Organization Science, 5(1), 51-71.

Stone, E. F., \& Hollenbeck, J. R. (1984). Some issues associated with the use of moderated regression. Organizational Behavior and Human Performance, 34, 195-213.

Tedeschi, T. J., \& Reiss, M. (1981). Verbal tactics impression management. In C. Antaki (Ed.), Ordinary Explanations of Social Behavior (pp. 271-326). London: Academic Press.

Van de Vijver, F., \& Hambleton R. (1996). Translating tests: some practical guidelines, European Psychologist, 1, 89-99.

Van Dyne, L., Graham, J. W., \& Dienesch, R. M. (1994), Organizational citizenship behavior: Construct redefinition, measurement, and validation, Academy of Management Journal, 37(4), 765-802.

Villanova, P., \& Bernardin, H. J., (1989). Impression management in the context of performance appraisal. In R. A. Giacalone \& P. Rosenfeld (Eds.), Impression Management in the Organization (pp. 299-313). Hillsdale, NJ: Lawrence Erlbaum.

Wayne, S. J., \& Ferris, G. R. (1990). Influence tactics, affect and exchange quality in supervisor-subordinate interactions: A laboratory experiment and field study. Journal of Applied Psychology, 75(5), 487-499.

Yaghoubi, E., Mashinchi, S. A., \& Hadi, A. (2011). An Analysis of correlation between organizational citizenship behavior (OCB) and emotional intelligence (El). Modern Applied Science, 5(2), 119-124. 
Yinon, Y., \& Landau, M. O. (1987). On the reinforcing value of helping behavior in a positive mood. Motivation and Emotion, 11(1), 83-93.

Yun, S., Takeuchi, R., \& Liu, W. (2007). Employee self enhancement motives and job performance behaviors: Investigating the moderating impact of employee role ambiguity and managerial perception of employee commitment. Journal of Applied Psychology, 92(3), 745-756.

Zedeck, S. (1971). Problems with the use of moderator variables, Psychological Bulletin, 76(4), 295-310. 